\title{
Archeological Testing in the De Dietrich (USA), Inc. Project Site Nueces County Texas
}

James E. Warren

Follow this and additional works at: https://scholarworks.sfasu.edu/ita

Part of the American Material Culture Commons, Archaeological Anthropology Commons, Environmental Studies Commons, Other American Studies Commons, Other Arts and Humanities Commons, Other History of Art, Architecture, and Archaeology Commons, and the United States History Commons

Tell us how this article helped you.

This Article is brought to you for free and open access by the Center for Regional Heritage Research at SFA ScholarWorks. It has been accepted for inclusion in Index of Texas Archaeology: Open Access Gray Literature from the Lone Star State by an authorized editor of SFA ScholarWorks. For more information, please contact cdsscholarworks@sfasu.edu. 


\section{Archeological Testing in the De Dietrich (USA), Inc. Project Site Nueces County Texas}

\section{Licensing Statement}

This is a work produced for the Texas Department of Transportation (TxDOT) by the report producer. TxDOT and the report producer jointly own all rights, title, and interest in and to all intellectual property developed under TXDOT's contract with the report producer. The report may be cited and brief passages from this publication may be reproduced without permission provided that credit is given to both TXDOT and the report producer. Permission to reprint an entire chapter, section, figures or tables must be obtained in advance from either the Supervisor of the Archeological Studies Branch, Environmental Affairs Division, Texas Department of Transportation, 125 East 11th Street, Austin, Texas, 78701 or from the report producer. 
Archeological Testing

in the

De Dietrich (USA), Inc. Project Site

Nueces County

Texas

\begin{abstract}
Submitted to
The City of Corpus Christi

Texas
\end{abstract}

December 1988

Texas Antiquities Committee

Permit No.

Report No. 184

James E. Warren

George West, Texas 


\section{Abstract}

Subsurface testing of two archeological sites (41NU 256, 41NU257) near the upper end of Oso Creek in Nueces County, Texas failed to encounter any significant cultural resources which will be affected by a proposed drainage project. If there are any intact portions of the sites remaining, they are outside of the proposed construction right-ofway • 
Table of Contents

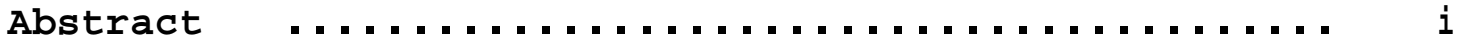

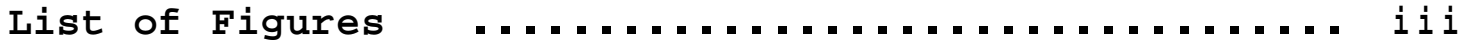

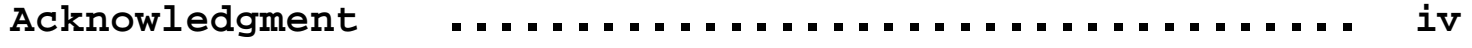

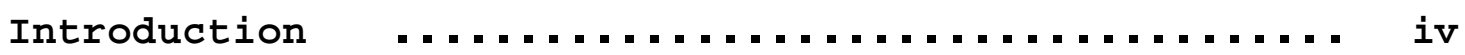

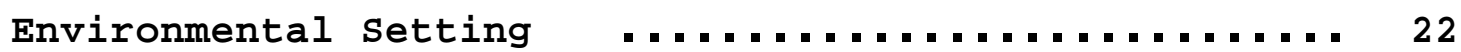

Historical Background ...................... 22

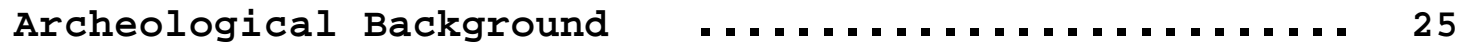

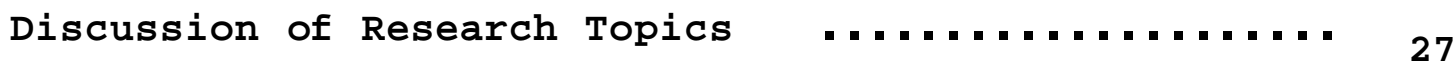

Integrity Criteria for Significant Sites ........ 29

Testing Methodology ..................... 31

Testing Results ........................ 34

Assessment and Discussion ................. 42

Significance Determination ................ 44

Recommendations $\quad . . . . . . . . . . . . . . . . . . . . .44$

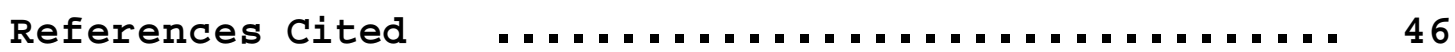




\section{List of Figures}

Fiqure

1. Vicinity Map

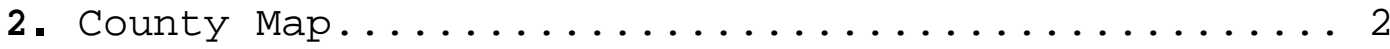

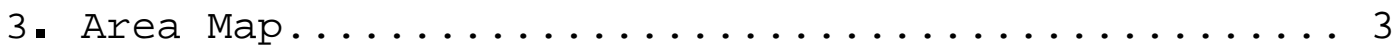

4. Plan Map of Testing Area.................. 4 .

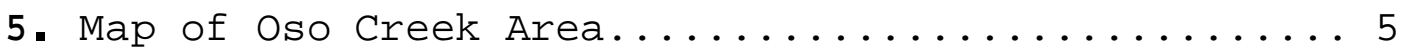

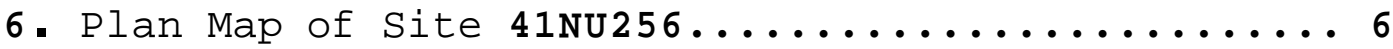

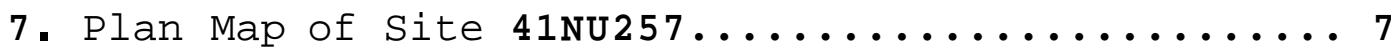

8. Profile of Test Unit $256-3 \ldots \ldots \ldots \ldots \ldots \ldots \ldots \ldots$

9. Profile of Test Unit $256-5 \ldots \ldots \ldots \ldots \ldots \ldots \ldots \ldots$

10. Profile of Test Unit $256-6 \ldots \ldots \ldots \ldots \ldots \ldots \ldots . \ldots 9$

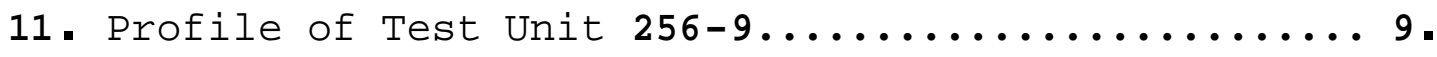

12. Profile of Test Unit 256-8................ 14

13. Profile of Test Unit $256-10 \ldots \ldots \ldots \ldots \ldots \ldots \ldots \ldots \ldots$

14. Profile of Test Unit $257-2 \ldots \ldots \ldots \ldots \ldots \ldots \ldots \ldots 11$

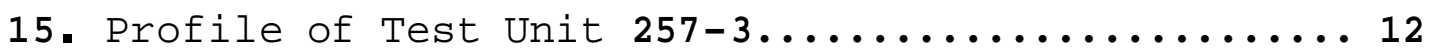

16. Profile of Test Unit 257-6............... 12

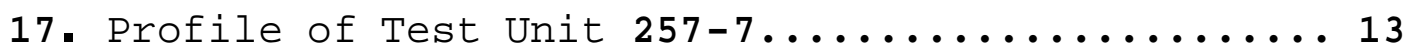

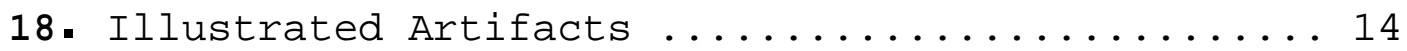


Acknowledgement

Greatly appreciated are the efforts of Tom Utter, Assistant City Manager, and Malcolm Mathews, Director, Development Services Center, City of Corpus Christi, for their cooperation during the planning and early implementation stages of the testing program. Also Chuck Urban of Urban Engineering was very helpful in furnishing plans of the proposed project and staking the right-of-way for the field crew. The assistance of Frank Wier, Archeologist with the Texas Department of Highways and Public Transportation was indispensible in coordinating efforts with his department and the Texas Antiquities Committee in Austin.

\section{Introduction}

In late November, 1988 the author completed a surface survey of the proposed De Dietrich (USA) Inc. drainage project for the city of Corpus Christi. During this survey (Warren 1988) two Aboriginal open campsites (41NU256, 41NU 257) were located within the proposed ditch right-of-way. Evidence of the sites included scattered artifacts and cultural debris on the surface which had been dispersed by farming practices. In order to attempt locating any intact portions of the sites and determine their significance a program of subsurface testing was recommended in consultation with the State Historic Preservation officer in Austin.

permission'to implement the testing program was received from the City on December 7, and the field work was performed between December 13 and 29 requiring approximately 120 person/hours to complete. The field crew consisted of the author, Skip Kennedy, Nancy Beaman, Mark Beaman, John McGee, and John Gallagher. Joyce Warren typed the draft and final copies of the report.

Since the drainage right-of-way belongs to the Texas Department of Highways and Public Transportation, and upon recommendations of that department the testing was performed under Texas Antiquities Committee Permit no. Artifacts will be curated at the Corpus Christi Museum, Corpus Christi, Texas. 
Figure No.1.

VICINITY MAP
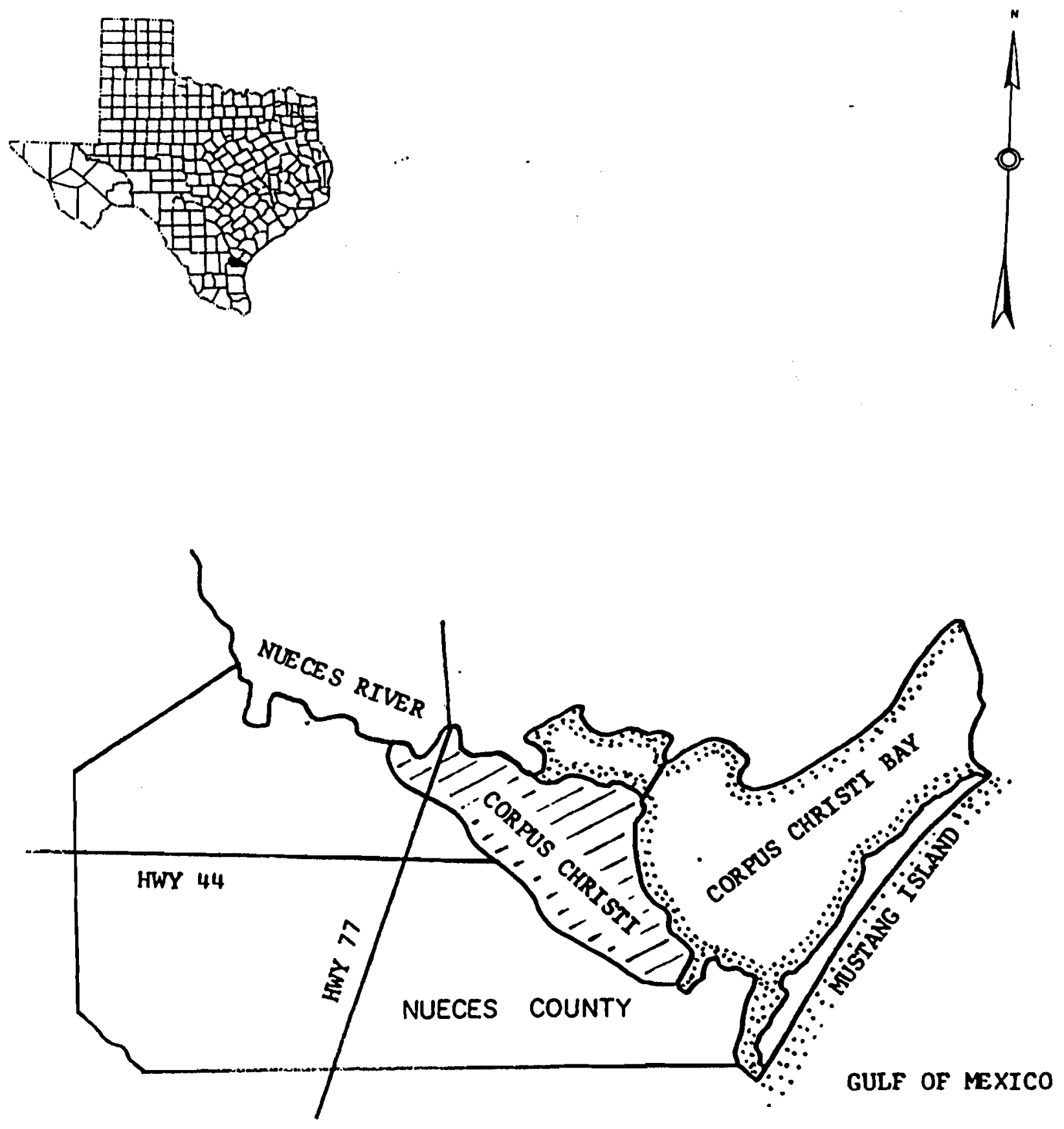

NO SCALE 
This Page Redacted Per THC Policy 
This Page Redacted Per THC Policy 
This Page Redacted Per THC Policy 
Figure No.5. Map of Oso Creek Area.

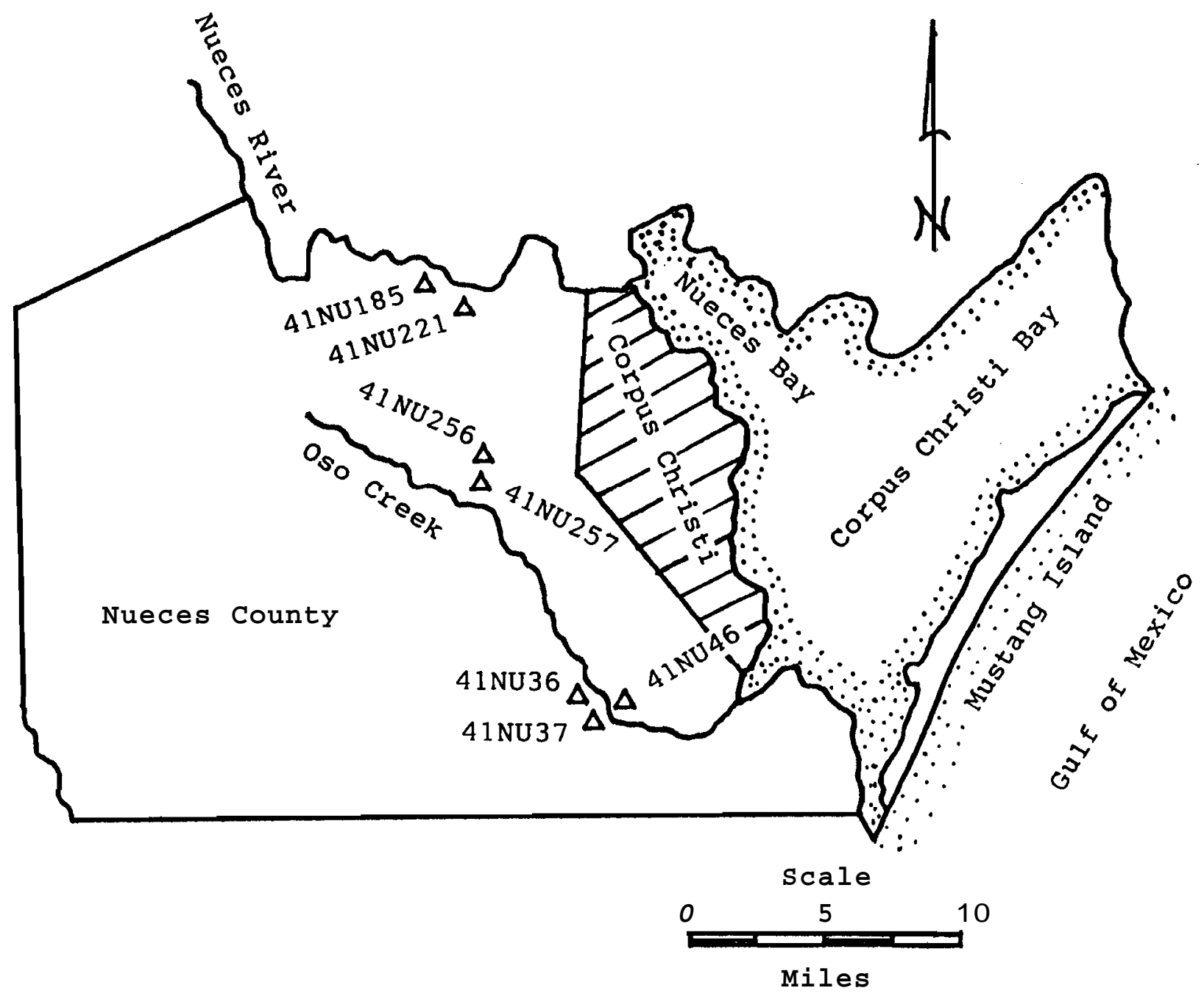


Figure No.6. Plan Map of Site 41 NU256.
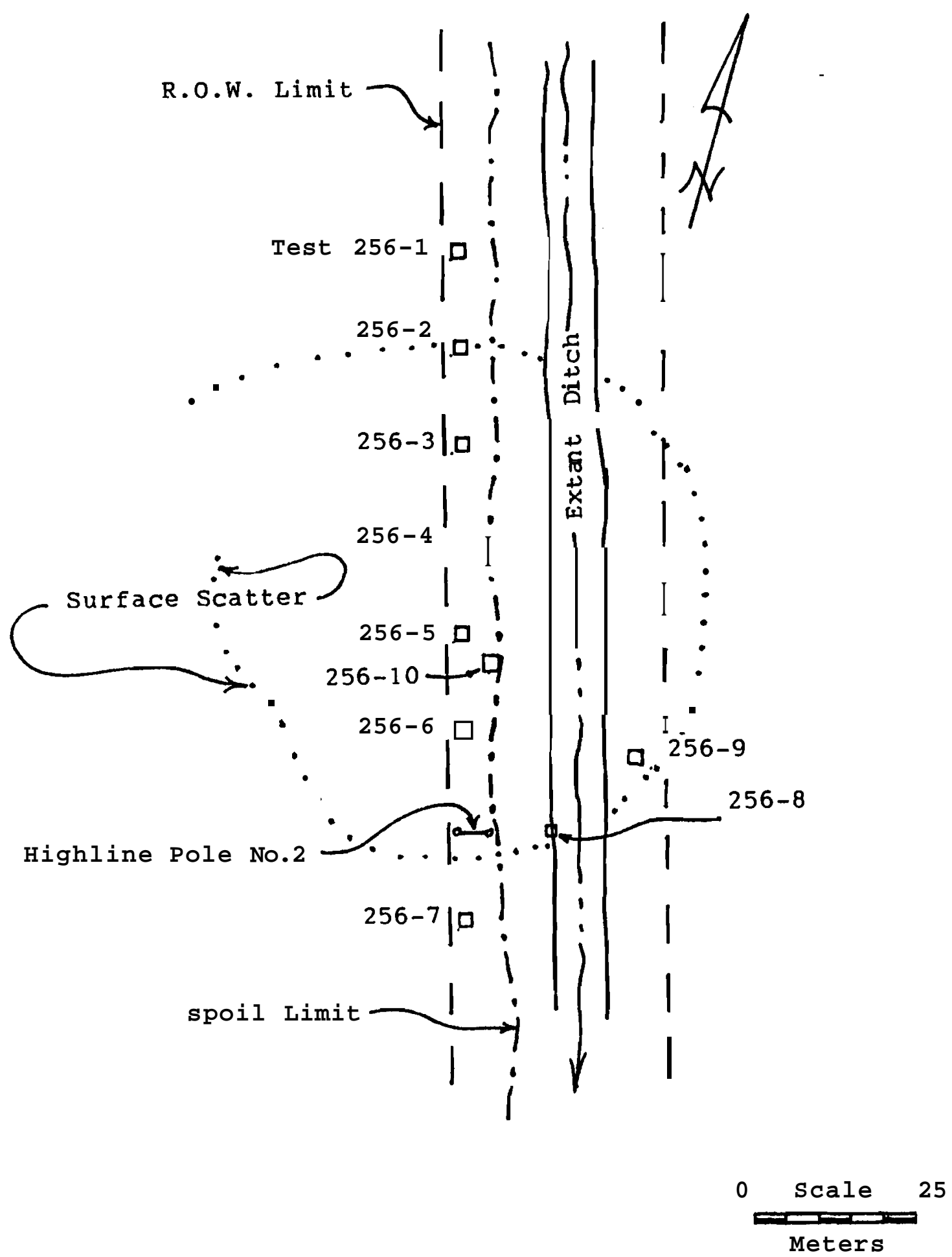
Figure No. 7. Plan Map of Site 41NU257.

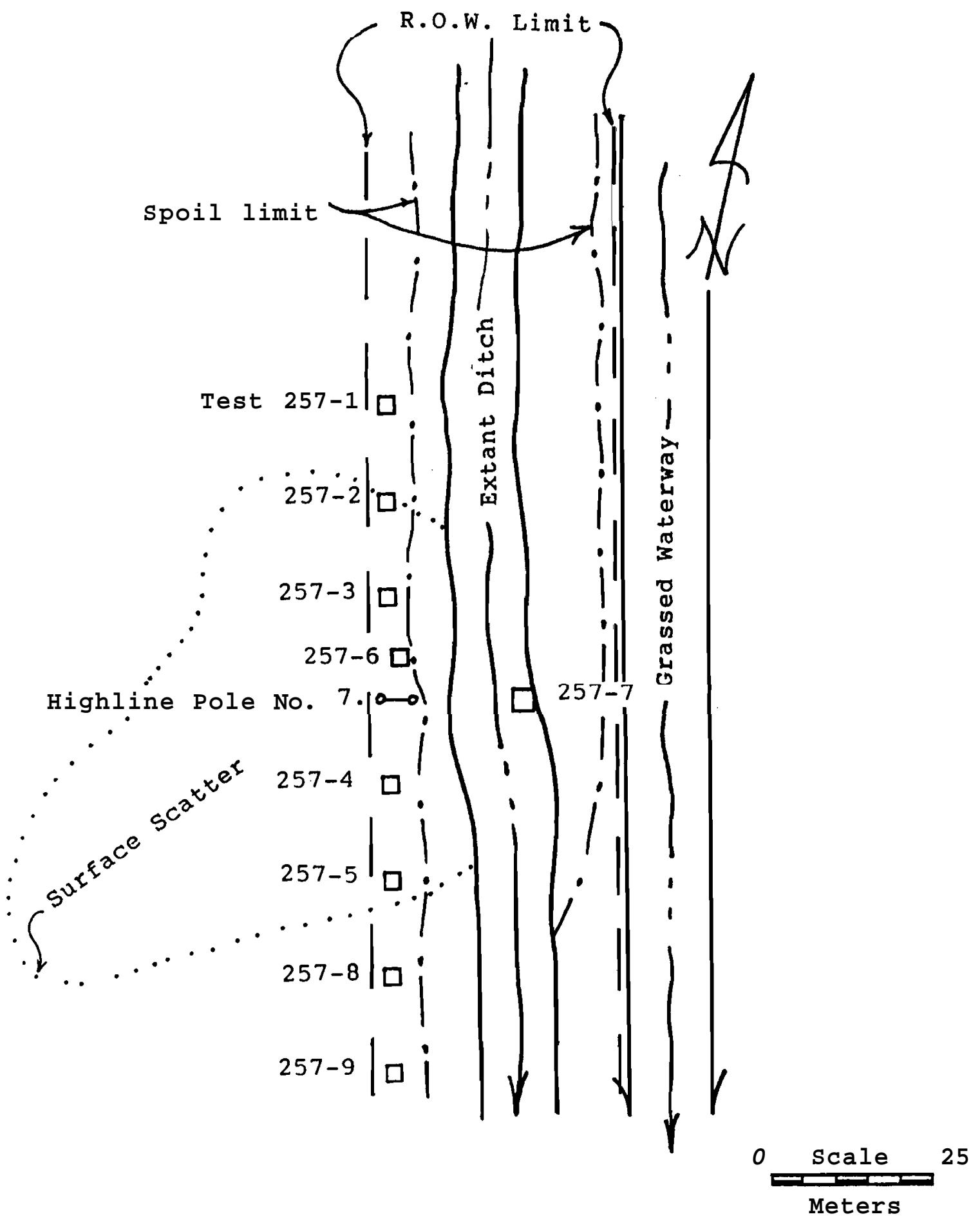


Legend for Figure No. 8.

A. (10YR4/2) dark grayish brown fine sandy loam.

B. (10YR3/1) very dark gray sandy clay.

C. (10YR6/2) light brownish gray loamy clay.

D. Soil surface.

E. Bottom of test unit.

Legend for Figure No. 9.

A. (10YR4/2) dark grayish brown fine sandy loam.

B. (10YR3/1) very dark gray sandy clay.

C. (10YR6/2) light brownish gray loamy clay.

D. Soil surface.

E. Bottom of test unit. 
Figure No.8. Profile of Test Unit 256-3.

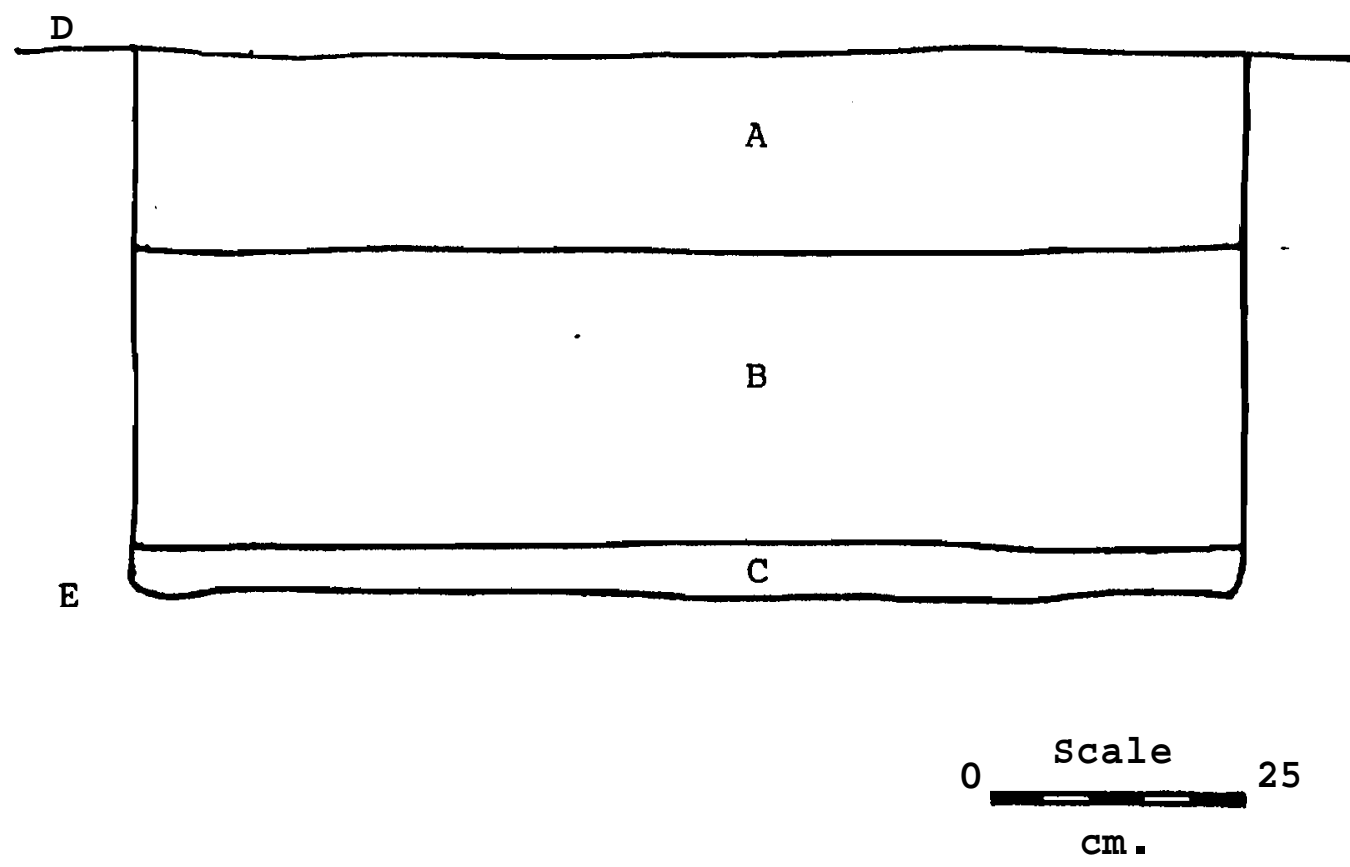

Figure No.9. Profile of Test Unit 256-5.

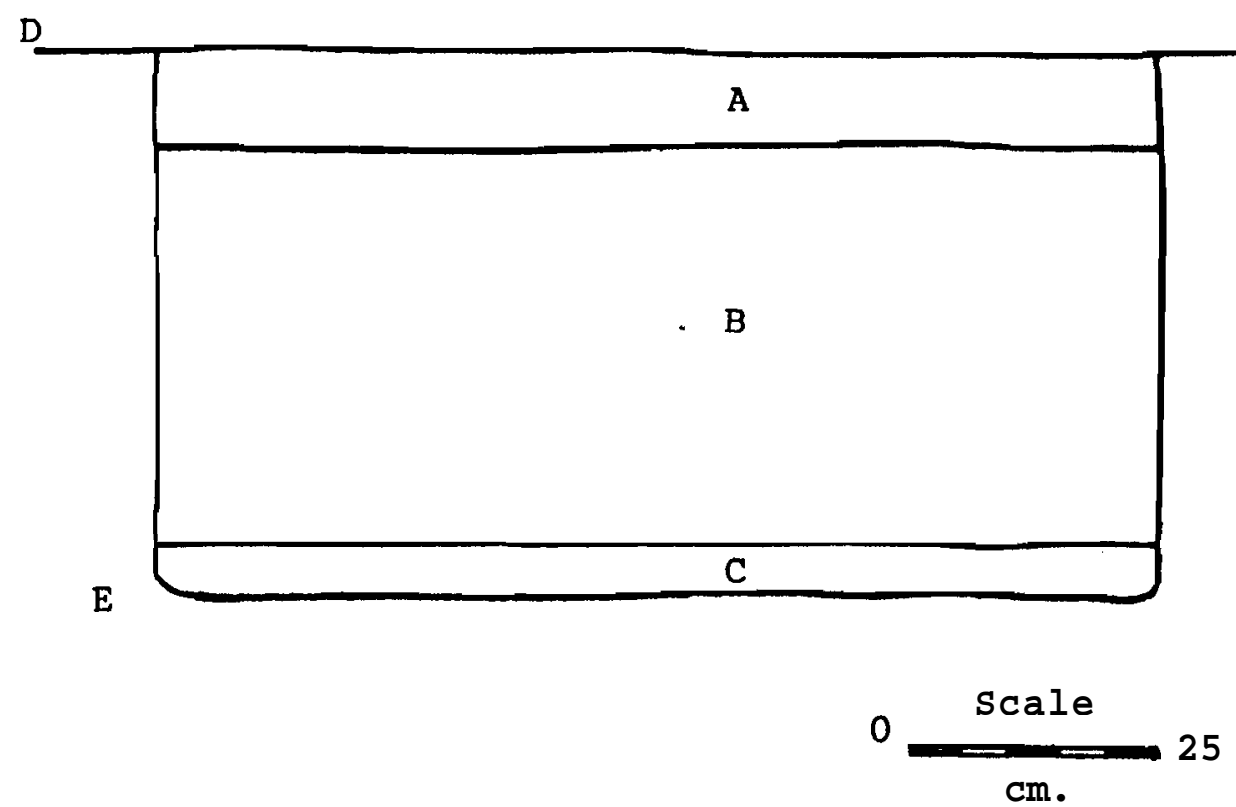


Legend for Figure No. 10.

A. (10YR4/2) dark grayish brown fine sandy loam.

B. (10YR3/1) very dark gray sandy clay.

C. (10YR6/2) light brownish gray loamy clay.

D. Soil surface.

E. Bottom of test unit.

x. Burnt clay nodules.

Legend for Figure No. 11.

A. (10YR4/2) dark grayish brown fine sandy loam.

B. (7.5YR N2/1) Black sandy clay.

C. (10YR5/1) gray clayey silt.

D. Soil surface.

E. Bottom of test unit. 
Figure No.10. Profile of Test Unit 256-6.

D
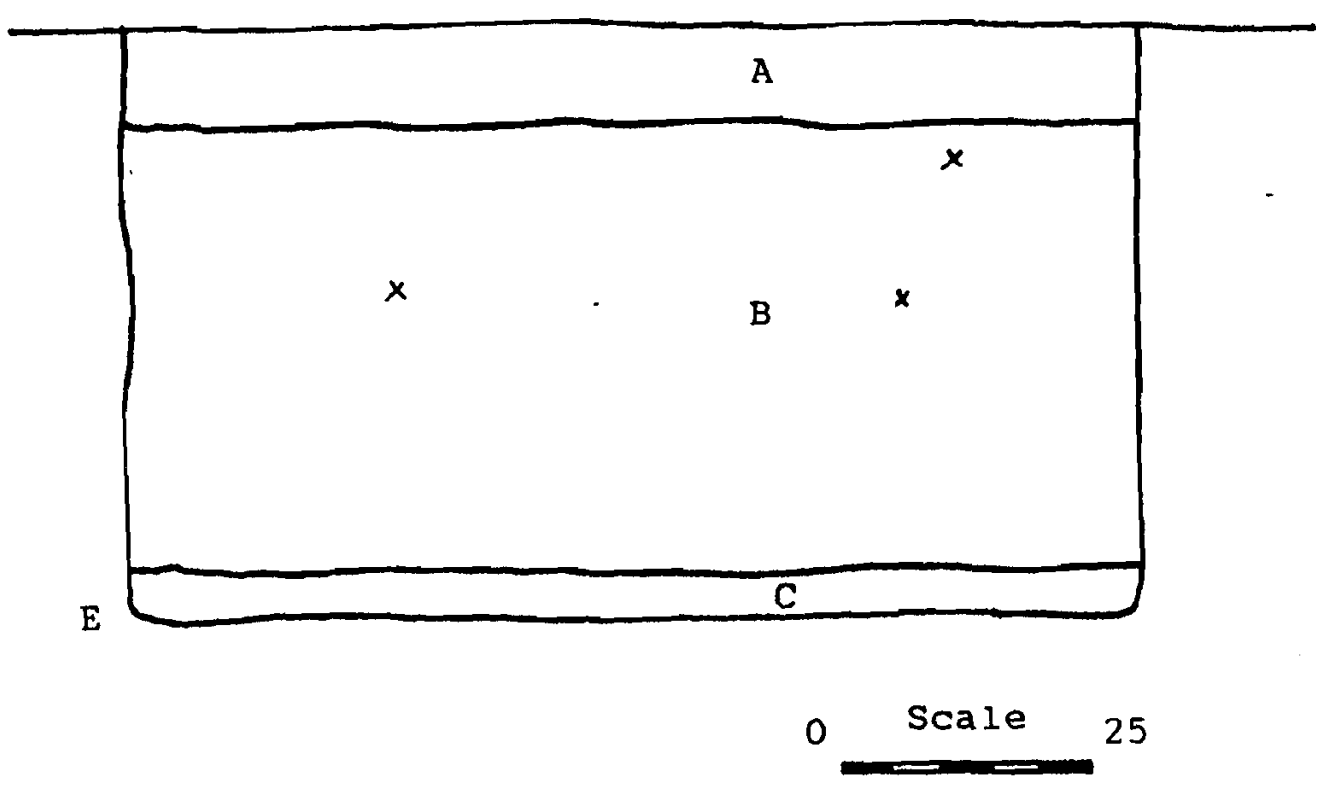

$\mathrm{cm}$.

Figure No.11. Profile of Test Unit 256-9.

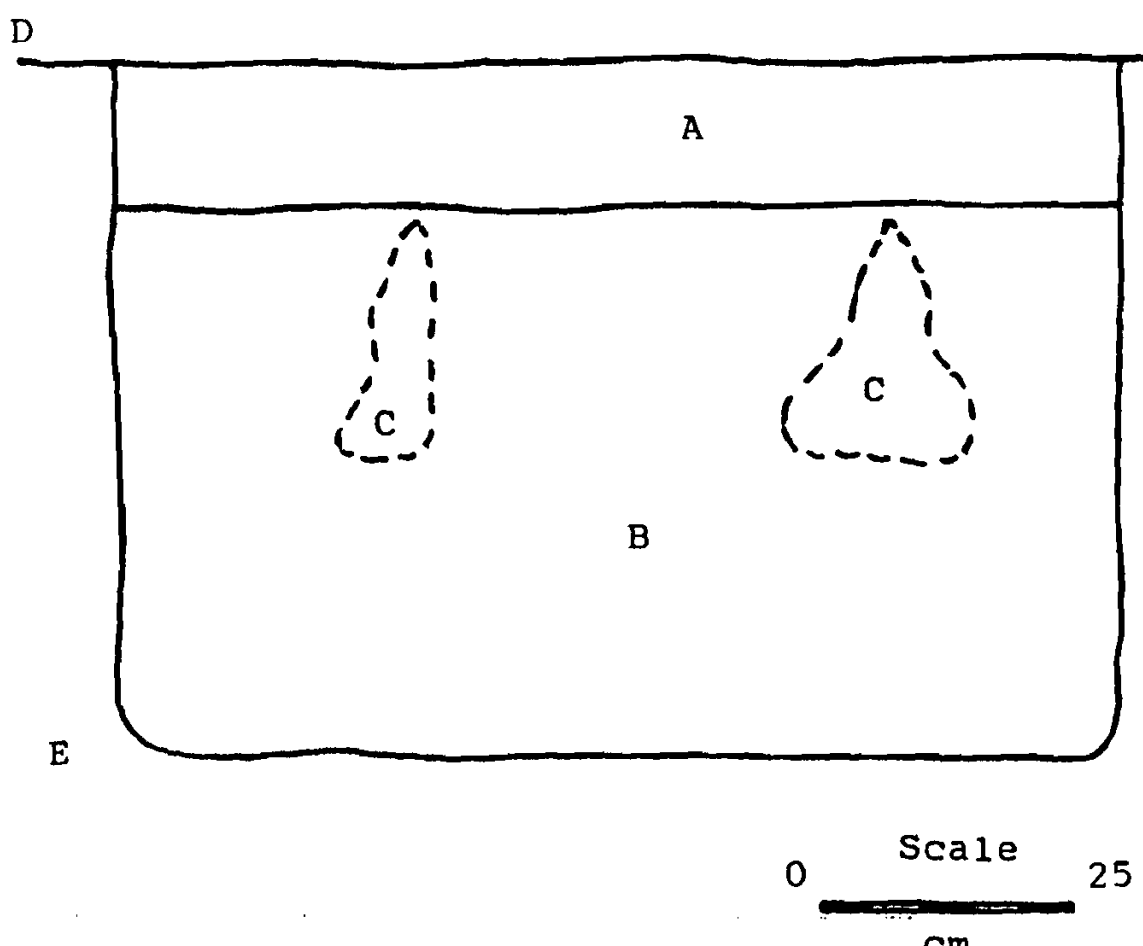

$\mathrm{cm}$. 
Legend for Figure No. 12.

A. (10YR4/2) dark grayish brown sandy loam.

B. (10YR3/1) very dark gray sandy clay.

C. Possible remnant of previous ditch backslope.

D. (10YR7/1) light gray silt strata alternating with (10YR4/2) dark grayish brown fine sandy loam strata.

E. (10YR7/1) light gray silt strata alternating with (10YR4/2) dark grayish brown fine sandy loam strata. F. Present soil surface on ditch backslope.

G. Bottom of test unit.

H. Present ditch bottom. 


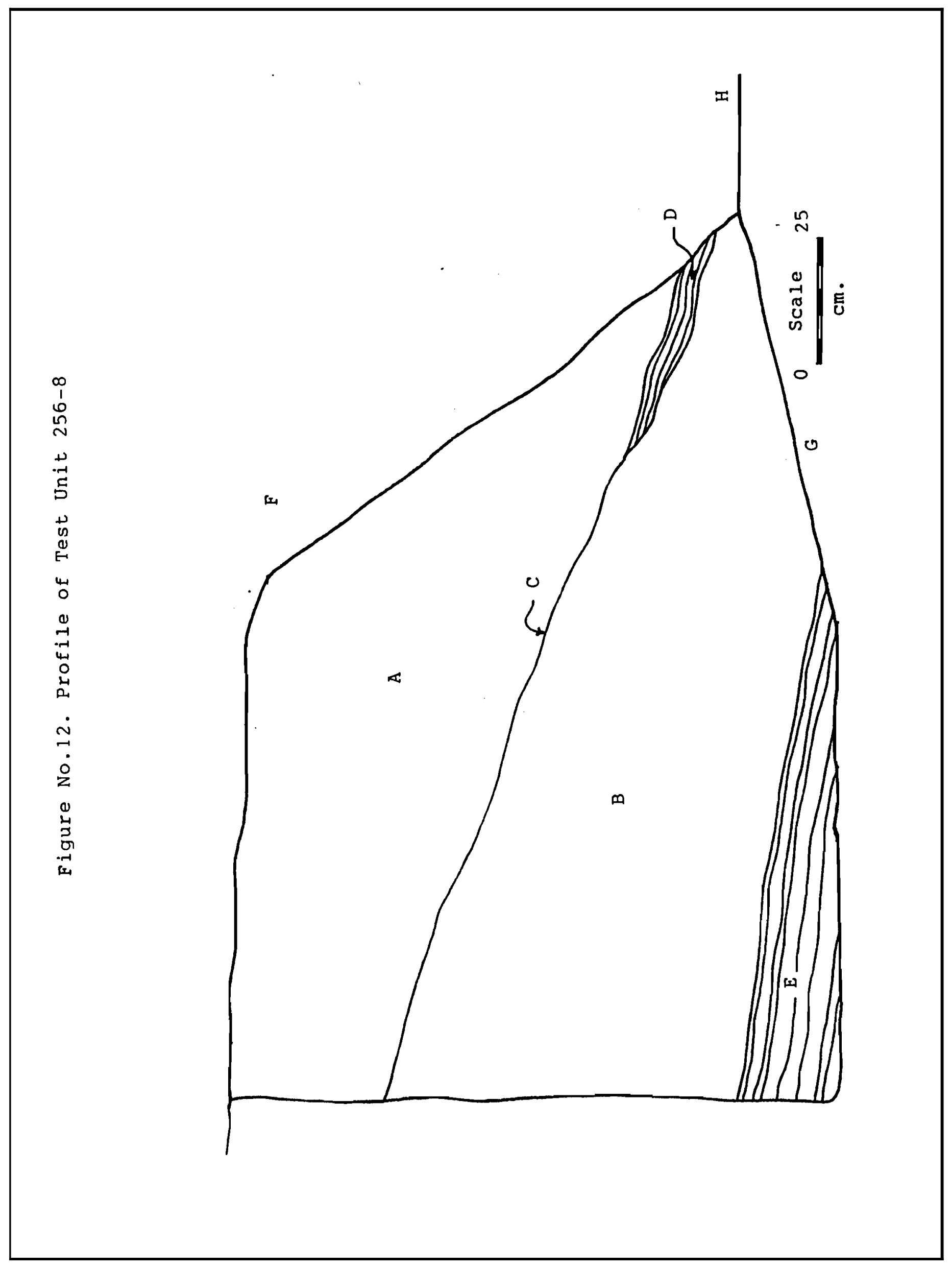


Legend for Figure No. 13.

A. (10YR4/2) dark grayish brown fine sandy loam.

B. $(10 Y R 3 / 1)$ very dark gray sandy clay.

C. $(10 Y R 6 / 2)$ light brownish gray loamy clay.

D. Zone of scattered Rabdotus fragments.

E. Soil surface

F. Bottom of test unit.

$\mathrm{x}$. Burnt clay nodules.

Legend for Figure No. 14.

A. (10YR4/2) dark grayish brown fine sandy loam.

B. $(10 Y R 3 / 1)$ very dark gray sandy clay.

C. (10YR6/2) light brownish gray loamy clay.

D. Cultural zone with scattered burnt clay nodules, Rabdotus shell fragments, charcoal flecks.

E. Soil surface.

F. Bottom of test unit.

$\mathrm{x}$. Burnt clay nodules. 


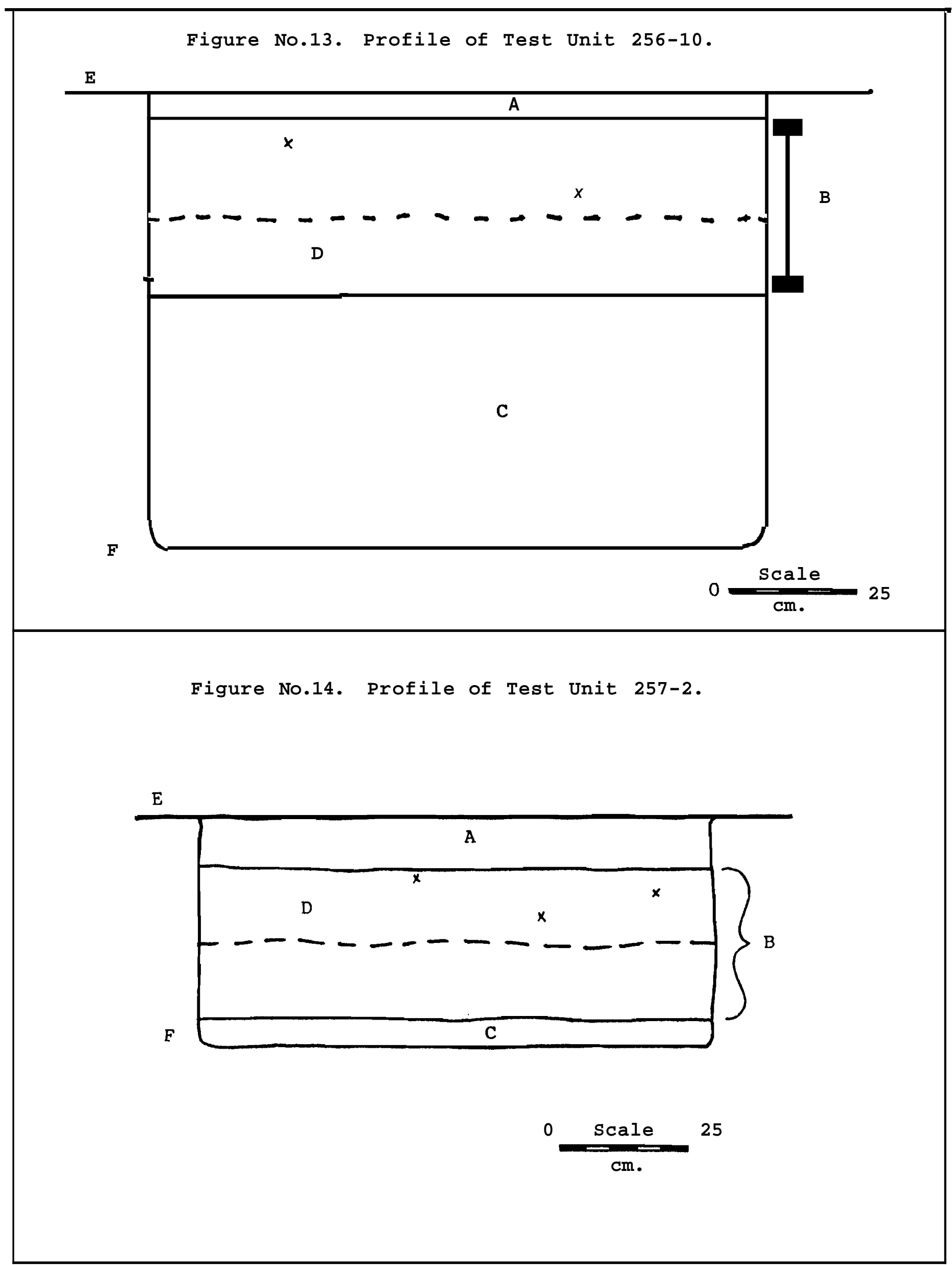


Legend for Figure No. 15.

A. (10YR4/2) dark grayish brown fine sandy loam.

B. (10YR3/1) very dark gray sandy clay.

C. (10YR6/2) light brownish gray loamy clay.

D. Zone of heavy cultural evidence, Rabdotus shell, Burnt clay nodules, charcoal flecks.

E. Zone of light cultural evidence, same as "D", but much lighter concentration.

F. Soil surface.

G. Bottom of test unit.

Legend for Figure No. 16.

A. (10YR4/2) dark grayish brown fine sandy loam.

B. (5YR2.5/1) black sandy clay.

C. (10YR6/2) light brownish gray loamy clay.

D. Soil surface.

E. Bottom of test unit.

$\mathrm{x}$. Burnt clay nodules. 
Figure No.15. Profile of Test Unit 257-3.
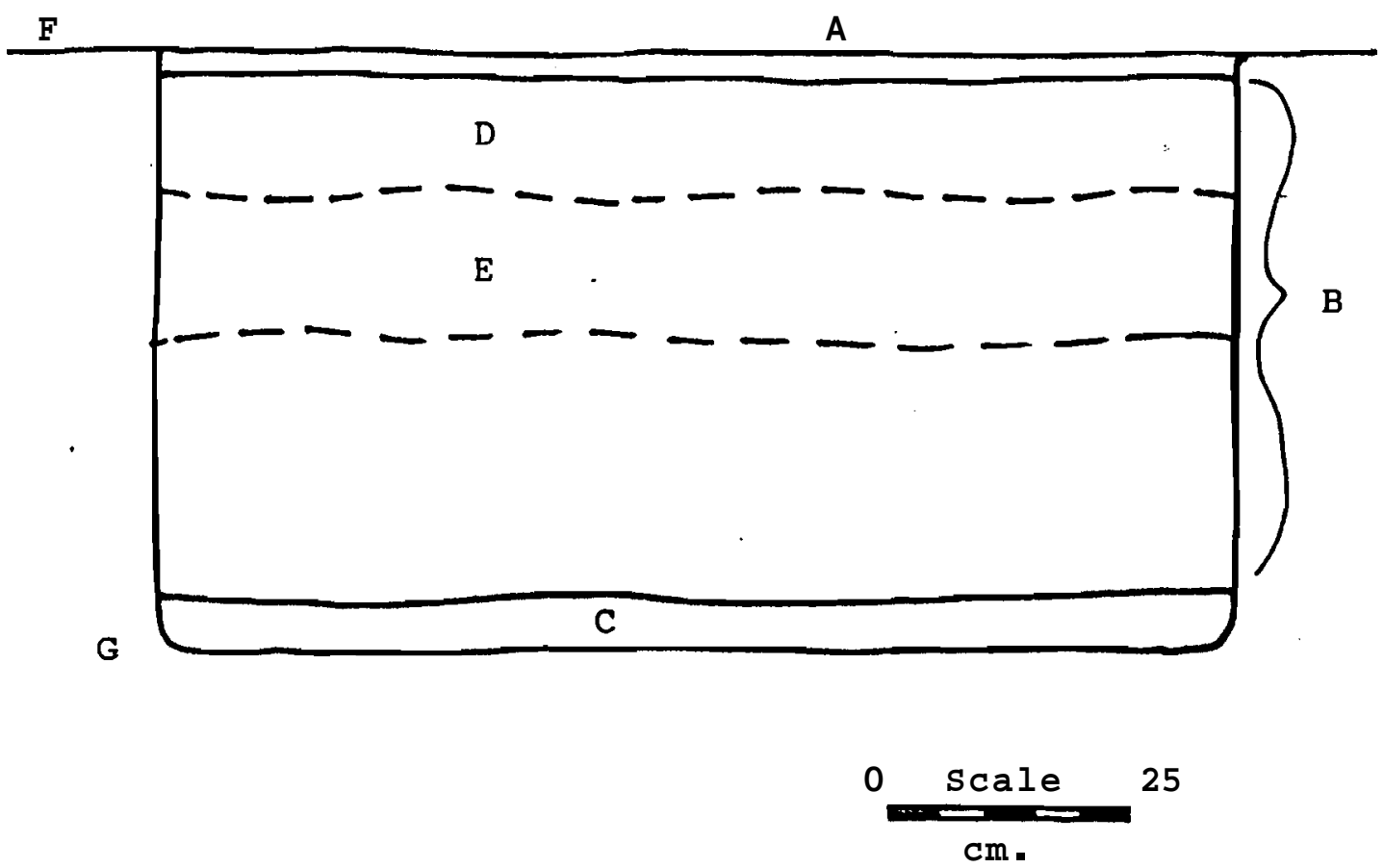

Figure No.16. Profile of Test Unit 257-6.

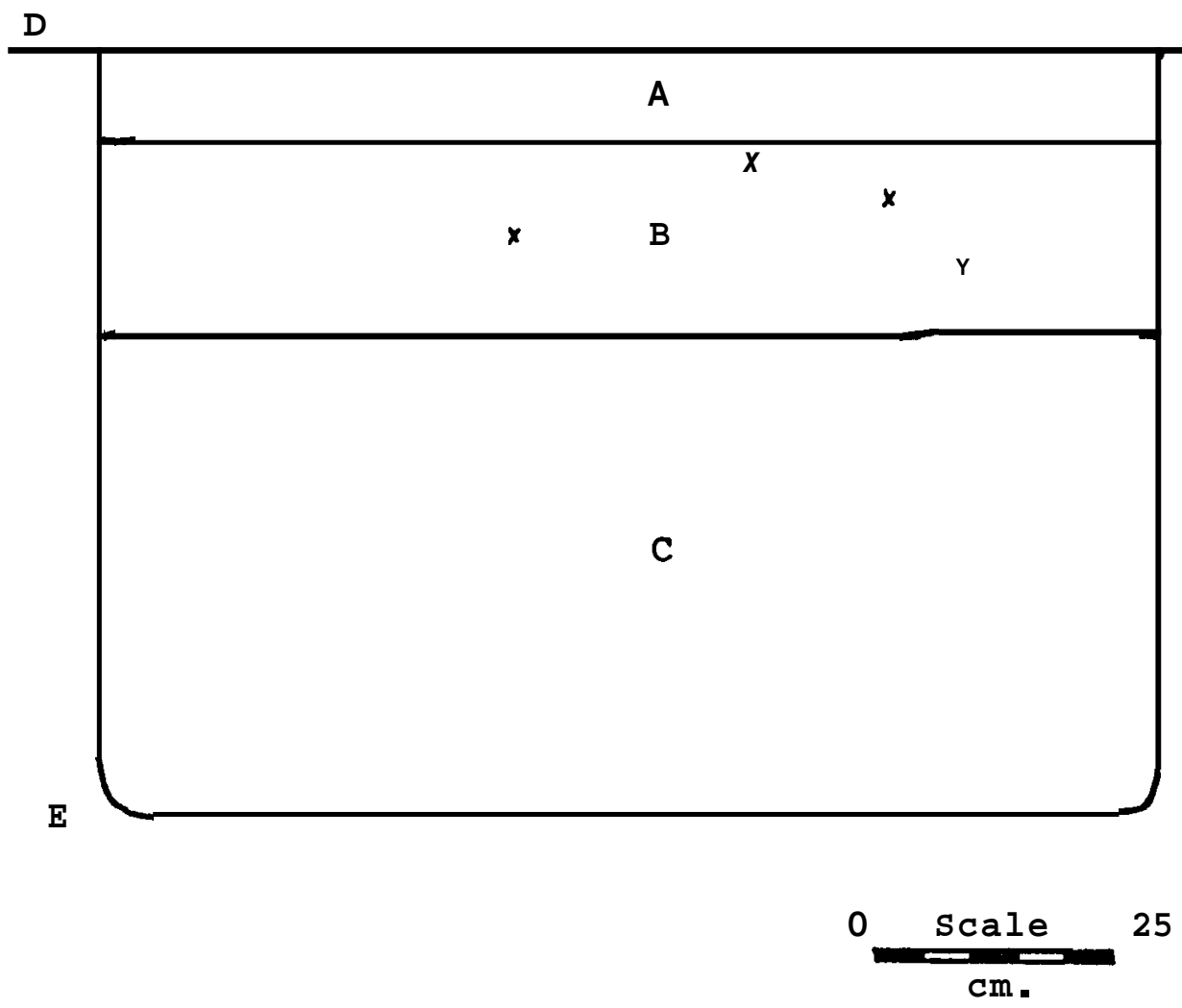


Legend for Figure No. 17.
A. (10YR3/1) very dark gray loamy clay.
B. (5YR2.5/1) black clay.
C. (10YR5/2) grayish brown clay.
D. Dry-weather cracks.
E. Bottom of test unit.
F. Present ditch bottom.
G. Soil surface.
H. Previous ditch backslope. 
Figure No.17. Profile of Test Unit 257-7.

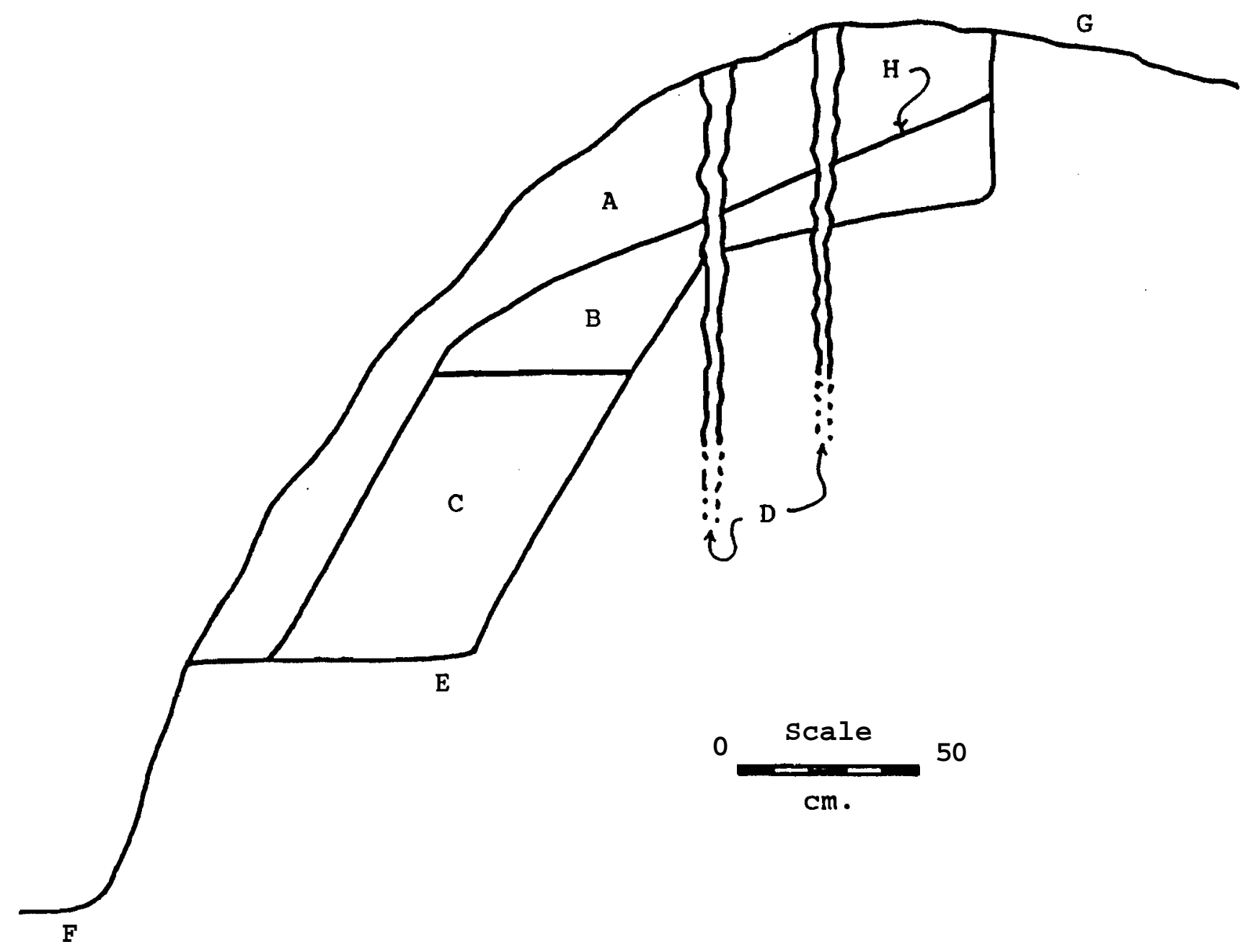


Legend for Figure No. 18.

Artifact 257-1. Chert hammerstone, (5YR3/2) grayish brown cortex, (10YR6/2) pale yellowish brown interior, cylindrical, fractured on both ends, numerous hammer scars on body, good quality, opaque.

Artifact 257-2. Chert expended core, (10YR5/4) moderate yellowish brown interior, mottled with (10YR4/2) dark yellowish brown inclusions, no cortex, numerous edge fractures, good quality, opaque.

Artifact 257-3. Chert percussion flake, (10YR6/2) pale yellowish brown interior, no cortex, good quality, opaque. Artifact 257-4. Chert percussion flake, (10YR6.5/3) pale yellowish orange interior, no cortex, good quality, opaque, utilized.

Artifact 257-5. Chert percussion flake, (10YR3/3) grayish moderate brown interior, (5YR2/2) dusky brown cortex, secondary flake, good quality, translucent, utilized.

Artifact 257-6. Chert chip, utilized, (10YR5.5/3) moderate yellowish brown interior, no cortex, good quality, opaque.

Artifact 257-7. Catán dart point, (10YR6/2) pale yellowish brown interior, no cortex, base thinned both sides, good quality, opaque, may be reworked point.

A11 artifacts were located on the disturbed surface in the cultivated field portion of the drainage R.O.W. Since only one secondary flake and no primary flakes were recovered it appears that the occupants of Site 41 NU257 were finishing tools and projectiles from blanks or trimmed cores. Also they were probably reconditioning damaged specimens.

As usual in sites along the coast, most of the chert flakes have been fortuitously utilized for some unknown chore. 
Figure No. 18. Illustrated Artifacts.

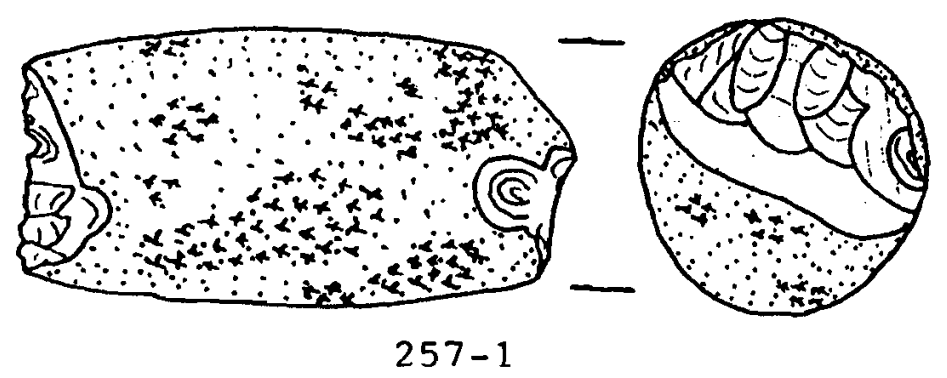

it

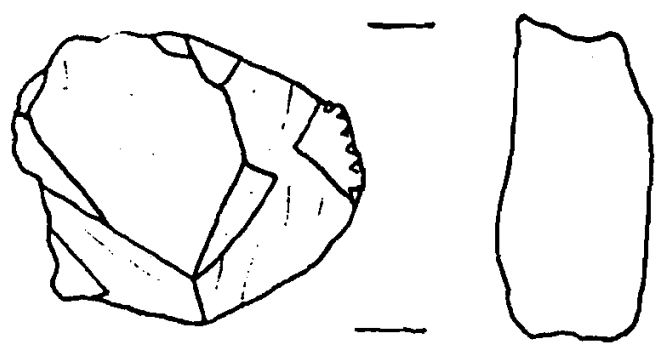

$257-2$

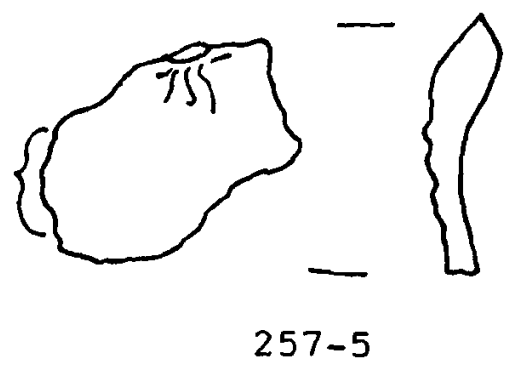

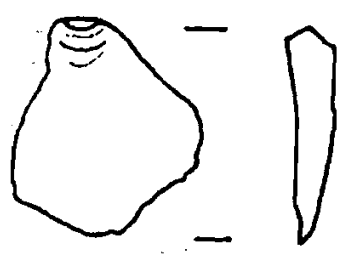

$257-3$
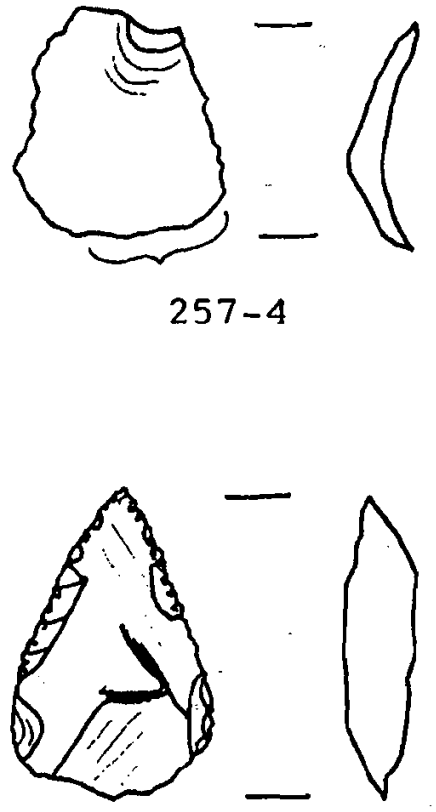

$257-7$

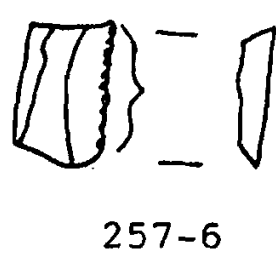

Actual size.

21 


\section{Environmental setting}

The proposed DeDietrich project is located in the western edge of the City of Corpus Christi at the intersection of State Highway 44 and McKenzie Road. Nueces County, of which Corpus Christi is the county seat, is situated in the Lower Coastal Plain Physiographic Region of Texas adjacent to the Gulf of Mexico (Kier, et al 1977:cover). Vegetation in the county is characteristic of the Gulf Prairie Vegetational Area of Texas which includes mid to tall grasses, forbs and invading brush species such as mesquite, granjeno, blackbrush, and numerous cacti. The terrain in this area is a nearly level, slowly drained plain less than 150 feet above sea level dissected by streams flowing to the gulf(Gould 1962:8). Elevations in the survey area range from 45 to 60 feet.

Soils in the project area are classified as Victoria clay and Clareville clay loam complex soils (Franki, et a 1 1965:2). The climate in the county is humid and subtropical in nature with temperatures averaging in the 80's and 90's in summer and 50's and 60's in winter. Average annual rainfall is 25 inches with a growing season of 335 days (Op Cit). Nueces county is considered to be located on the northern edge of the Tamaulipan Biotic Province and'lists at least 61 species of mammals, 36 species of snakes, 19 of lizards, two land turtles, 3 urodeles, and 19 anurans in its' faunal inventory (Blair 1950:103).

\section{Historical Background}

That part of Texas which includes present Nueces County was one of the earliest to be explored on the Texas Gulf Coast. In 1519, just 24 years after Columbus discovered the New World, Alonzo Álvarez de Piñeda sailed into Corpus Christi Bay while mapping the Gulf coast for the king of Spain. De Piñeda is credited with naming the bay for the feast day of Corpus Christi by Franki (1965:59) while Webb (1952: 
Vol. I, 415) gives the credit to Diego Ortiz Parrilla in

1766 .

At least one writer (Baskett 1907: 259) believes that Cabeza de Vaca and his fellow survivors of the Narvaez expedition spent at least one winter in the vicinity of the mouth of the Nueces River during their stay with the Karankawa Indians between 1528 and 1534 .

The French left their mark on the area in 1685 when Rene Robert Cavalier, Sieur de La Salle landed in the vicinity of Corpus Christi before proceeding further up the coast to establish Fort Saint Louis at the head of Lavaca Bay in present Victoria County (Deviney 1933:27).

In the early 18th century Spain launched an intensive campaign to settle northeastern Mexico and southern Texas. In 1746 José de Escandón was commissioned by the Spanish Viceroy to settle colonists on the Gulf Coast from the Rio Pánuco to the San Antonio and Medina Rivers and inland a distance of 60 to 80 leagues. This enormous new province was named Colonia del Nuevo Santandér (Bolton 1970: 292). While searching for suitable sites in the local area Captain Joaquin de Orróbio y Bazterra is credited with discovering that the Nueces River flows into the Gulf rather than the Rio Grande as previously reported (ibid: 293).

The first successful Spanish settlement in the area of present Corpus Christi was in 1766 when Blas Maria de la Garza Falcón established his ranch headquarters near the present town of Petronila on his El Chiltipin land grant (Patterson and Ford 1974:20).

In 1821 Mexico won its' independence from Spain and the Spanish province of Nuevo Santandér became the Mexican Free State of Tamaulipas. Soon thereafter recorded Mexican land grants in the area included ten leagues of land granted to Enrique Villareal in 1831 and known as Rincón del Oso (Op cit). Villareal was in charge of the Mexican garrison at Fort Lipántitlán on the Nueces River across from the present settlement of San Patricio from 1828 to 1835 (Webb 1952: 20). 
The area now known as Corpus Christi became the first Anglo settlement west of the Nueces River in 1839 when Henry L. Kinney and William Aubrey bought a portion of Villareals' grant and established a ranch and trading post at the site (Riley 1951:15). In 1840 Kinney began transactions which eventually concluded in his purchase of the en-tire Rincón del Oso grant which contained those lands between the Nueces River and Oso Creek including the present De Dietrich project site (Patterson and Ford 1974:22). 
Archeological Background

In any discussion of regional concepts of cultural adaptations a review of the major archeological sites involved is necessary. In many cases there has been very little work done in the past leaving a dearth of information available concerning these sites. Fortunately, along the central portion of the Texas coast there have been a number of important sites reported although many of these have only been subjected to limited testing and not to controlled excavations. A review of sites considered important in the area of our present endeavor follows:

41NU46, The Tucker Site (Fig. 5).

Located on the left (east) bank of Oso Creek on the crest and flanks of a prominent clay dune, this site was excavated by Herman Smith and a group of Corpus Christi Museum volunteers in 1985 (Smith et al 1985, ms). It appears to be a large, mainly Archaic, habitation site which has been greatly disturbed by erosion and vandalizing and is presently endangered by construction of a housing development. Smith (1985) believes he has found evidence of perhaps daub-and-wattle structures and earth ovens used in processing the ubiquitous Rabdotus snail. A thin remnant of Late Prehistoric occupation may remain in the northern portion of the site (Warren 1984) containing Rockport ceramics and arrow points, but may also have been destroyed by erosion and recent earthmoving operations.

Marine faunal remains are fairly abundant on the site including oyster, whelk, clam and scallop shells, fish bones and otoliths. Many of the shell fragments have been modified and utilized as tools and weapons (adzes, scrapers, arrow points). Also found in large numbers are shells of the Rabdotus land snail, many of which are accumulated in great "piles". The everpresent (in this area) burnt clay nodule also appears in localized accumulations as well as scattered thinly over the entire site. 
41NU37, The Oso Dune Site (Fig. 5).

Located on the right (west) bank of Oso Creek directly across from 41NU46, this Aboriginal cemetery has been looted by vandals and collected by avocationists for 40 or 50 years. It has also been greatly disturbed by erosion which lures vandals to the site following each rainy spell to see if any additional burials have been revealed. To date very little evidence of prolonged occupation has been encountered. It has been estimated that more than 50 burials were destroyed prior to 1987 when some measure of protection was afforded by establishment of the Corpus Christi Botanical Garden immediately upstream from the site.

Recently Herman Smith and the C. C. Museum Volunteers have been excavating burials on the site and hopefully some well-documented information will be forthcoming upon publication of the results (Herman Smith-personal communication).

Late Prehistoric artifacts including Rockport ceramics, Perdiz and Fresno arrowpoints, freshwater musselshell ornaments, bird-bone beads and utilized chert flakes are found on the eroded surface. 41 NU36 (Fig. 5).

Immediately upstream and across a small intermittent stream from 41NU37, is a small occupational site which may be associated with the burials at the oso Dune site. Rabdotus shells, burnt clay nodules, marine shell, Rockport ceramics and dart points have been reported on the surface (Patterson and Ford 1974, Ricklis 1987) indicating the possibility of Archaic as well as Late Prehistoric components at the site. 41NU185, The Allison Site (Fig. 5).

Located on a prominent hill overlooking the right bank and floodplain of the Nueces River this site was recorded and tested by Carlson, Steele and Bruno in 1982. The occupation site contained a possible oyster shell midden as well as numerous Rangia shells, Rockport ceramics, deer bone, and lithic debitage. It is believed to contain both Archaic and Late Pre- 
historic components (Carlson et a 11982 , i).

41NU221, The McKinzie Site (Fig. 5).

Located similarly as the Allison Site this occupation area has been recently excavated and reported by Bob Ricklis (1987). The site contains a Rangia shell midden as well as evidence of possible shelters (post molds); discreet Archaic and Late Prehistoric components; mammal and fish remains; marine shell; lithic tools, points and debitage; and Rockport ceramics.

\section{Discussion of Research Topics}

As with most archeological investigations more questions are generated than answered as a general rule. A few of the major questions or topics for research which appear pertinent in this area of the Texas Coast are:

A. Are there discreet temporal components in coastal zone sites?

1. Necessary site characteristics.

a. Occupation sites with depth of profile and definite separation of strata.

b. Presence of temporally diagnostic artifacts or dateable material such as charcoal, shell, bone, ceramics, etc.

B. What was the subsistence pattern of Aborigines and what, if any, changes occurred through time?

1. Necessary site characteristics.

a. Temporary and long-term occupation sites and foraging sites with depth of profile and definite separation of strata.

b. Presence of temporally diagnostic artifacts or dateable material such as charcoal, shell, bone, ceramics, etc. Preservation of floral and faunal material. 
C. Were sites occupied seasonally or yearlong?

1. Necessary site characteristics.

a. Occupation sites with depth of profile and definite separation of strata.

b. Preservation of floral and faunal material such as Rabdotus shells, Rangia shells, fish otoliths, bones of migratory birds, plant pollen, etc.

D. Is there evidence of Aboriginal dwellings or shelters?

1. Necessary site characteristics.

a. Minimally disturbed occupation sites with depth of profile.

b. Preservation of post molds, stakes or post stumps in place, evidence of daub-and-wattle construction such as burnt daub with definite wattle impressions, etc.

E. Is there evidence for trade with other cultures?

1. Necessary site characteristics.

a. Occupation sites relatively undisturbed.

b. Presence of culturally diagnostic artifacts or regionally diagnostic materials.

F. Are there patterns in cemetery locations and can cemeteries be identified with particular sites or time periods?

1. Necessary site characteristics.

a. Cemetery site or occupation sites with a cemetery component.

b. Well preserved human remains, grave goods, minimal disturbance. 


\section{Integrity Criteria for Significant Sites}

In this part of the Texas coast the predominant Aboriginal sites encountered are: shell middens, long-term campsites, short-term campsites, cemeteries, and single burials. A discussion of these sites and the minimum criteria for integrity of significant sites follows:

1. Shell Middens.

a. Marine shell middens.

These sites containing dense accumulations of marine shells (oyster, whelk, scallop, clam, etc.) are usually located along the coastline of bays and the laguna Madre, areas where these species were available in the past. They usually contain faunal material, lithics, and ceramics and occasionally dateable charcoal. Shell middens are fairly common although many have been disturbed or destroyed by shoreline erosion and construction projects. A number of them have been excavated with mixed results.

Given their numbers and propensity to yield mixed results the minimum integrity for significance determination should be fairly high. They should contain dateable organic material in association with diagnostic artifacts or intact occupational strata and the strata should be separable.

b. Brackish water shell middens.

These sites containing dense accumulations of Rangia shells are usually located near streams or estuaries. They are usually not near enough to the shoreline to be affected by shoreline erosion. In fact they are generally in upland locales overlooking the riverine or estuarine environmental zone and are usually covered with alluvium or loess. Thus they have been protected until discovered during excavation or episodes of gully or sheet erosion or farming operations.

These middens usually are associated with an adjoining occupational site, but are occasionally found separately. Being less numerous (probably) than marine shell middens and given their precarious topographical situation (high 
ground overlooking rivers and estuaries) where they are subject to disturbance by urban growth and cultivation, the discovery of intact brackish water shell middens is rare and will probably continue to deteriorate.

Therefore, if an intact midden is discovered it should be considered significant. If only a portion of it is intact then that portion should contain, at a minimum, a sufficient number of intact shells for seasonality determination.

2. Long-term Campsites:

This type site is defined as one which contains prolific evidence of previous occupation (usually over a large area, but not necessarily) and some depth to its' profile. These sites usually contain lithic debris, ceramics, bone, shell, and burnt clay nodules and are most common near the coastline or a short distance upstream on lateral watercourses. Most commonly they are located on slight elevations such as clay dunes or other natural topographical features.

Being fairly common, and a number being excavated, integrity of these sites should be fairly high. Upon testing they should, as a minimum, contain portions of intact occupational strata over an area large enough to be reasonably expected to yield dateable organic material and/or diagnostic artifacts associated with such strata.

3. Short-term Campsites.

These sites, defined as containing similar artifactual evidence as long-term sites, but in much lesser amounts, are usually encountered further inland, many times on the same stream or drainage area as long-term sites, but occasionally at some distance from the stream. They are frequently encountered in cultivated fields or during shallow earthmoving operations concerned with construction of dwellings, roads, drainage ditches and utilities.

Many of these sites are probably one-time occupations of very short duration. They usually have very little depth in profile (if discovered intact), very few artifacts, and do 
not cover large areas. Since these sites are seldom discovered in undisturbed context their threshold of integrity should be very low. Almost any intact occupational stratum or cultural feature such as a hearth, shell accumulation or refuse midden should be considered significant.

4. Aboriginal Cemeteries.

These sites are located similarly to long-term campsites, namely near the coast and a short distance upstream on waterways. Although a number of these sites have been reported in this portion of the coast very little controlled data have been forthcoming from previous excavations. Aside from the fact that these are inhumations, and should be treated as such, any Aboriginal cemetery should be considered significant and capable of contributing important data concerning extinct cultures.

5. Single burials.

Single burials or small group burials are occasionally encountered during farming operations or construction activity or as a result of natural erosion. These burials occur in various locations, some near the coast, some near streams, but some also at great distances from the coast and inland streams.

As mentioned above these are inhumations and should be considered significant even though they are often discovered in disturbed context.

\section{Testing Methodology}

The right-of-way in question is only 100 feet wide and has an existing drainage ditch in the center which varies from 25 to 30 feet in top width. This leaves a long, narrow strip about 35 feet wide on either side of the ditch. This narrow strip, although belonging to the Texas Department of Highways and Public Transportation (TDHPT), is being cultivated by farmers on both sides of the ditch. Since the strip is long and narrow and any resources outside the right-ofway will not be affected by the project, a series of hand- 
dug test units parallel to the ditch was planned to define the areal extent and depth of each site within the rightof-way.

The tests averaged $1 \mathrm{~m} . x 35 \mathrm{~cm}$. in size and ranged from 45 to $120 \mathrm{~cm}$. deep. Matrix from the tests was screened through $1 / 4 \mathrm{in}$. mesh in $10 \mathrm{~cm}$. arbitrary levels. If cultural zones were encountered the levels would have been changed to coincide with the cultural zones. Artifacts were bagged separately by test unit and level.

The farmer on the west side of the ditch had disked his field following the original survey so another surface survey of the two sites was performed by the testing field crew. These artifacts were bagged separately from those of the test units.

It appears that spoil from the original ditch construction was all piled on the west side of the ditch. This is the "low" side and is the natural direction of flow of surface run-off in this field. Through the years cultivation has levelled this spoil until it only leaves $20-30 \mathrm{~cm}$. of cover on the natural ground within the right-of-way. The primary line of test units was placed near the edge of the remaining spoil in order that the tests would not be moving an excessive amount of spoil material that was obviously disturbed. After the primary tests were completed the secondary tests were placed nearer the ditch, well within the spoil area to test the theory that relatively undisturbed evidence might exist beneath the mantle of spoil material.

A third series of test units was then placed on the slopes of the extant ditch in an attempt to reveal the original profile of the ditch and any cultural evidence that may have been encountered during its construction.

Field notes were maintained by the author including sketches of all test unit profiles and plan maps of the test sites. Artifacts were cleaned, cataloged and analyzed in the laboratory. Matrix and soil samples were planned to be taken for 
radiocarbon dating and other pertinent analyses.

No photographs were taken since it appeared that they would not add anything meaningful to the data gathered in the field. 
Testing Results

Site 41NU256:

Surface Survey:

Since the area west of the ditch had been disked subsequent to the original survey it was surveyed again-adding nothing new to the surface collection. Burnt clay nodules, a few Rabdotus shell fragments, and a few oyster shell fragments were the extent of the surface artifacts observed. None were collected.

Although the field east of the ditch had not been freshly disked it was also surveyed with similar results, but much less evidence on the surface. Only 3 burnt clay nodules and one Rabdotus shell fragment were observed on that portion of Site 41 NU256 which lies on the east side of the drainage ditch.

The Subsurface Tests:

Unit 256-1.

This unit placed $90 \mathrm{~m}$. north of highline pole structure no. 2 (Fig. 6) and 15m. west of the west edge of the extant drainage ditch. This location is approximately 15 meters north of the northernmost surface evidence of the recorded site. The test was $1 \mathrm{~m}$. $x 30 \mathrm{~cm}$. in size and $45 \mathrm{~cm}$. deep. The profile revealed is normal for Orelia fine sandy loam soils in the eastern part of Nueces County (Franki et a 1 1965:15) exhibiting $15 \mathrm{~cm}$. of dark grayish brown (10YR 4/2) fine sandy loam, then $25 \mathrm{~cm}$. of a very dark gray (10YR3/1) sandy clay trending into a light brownish gray (10YR6/2) loamy clay subsoil.

No cultural evidence was encountered.

Unit $256-2$.

This unit was placed $75 \mathrm{~m}$. north of highline pole structure no. 2 (Fig. 6.) and $17 \mathrm{~m}$. west of the west edge of the extant drainage ditch. This location coincides with the northernmost edge of the surface evidence encountered at this site. The test was $1 \mathrm{~m}$. x $35 \mathrm{~cm}$. in size and $50 \mathrm{~cm}$. deep. 
Because the soil profiles are similar in all test units the discernible soil strata observed are designated A, B, C, etc. in the remainder of the test unit descriptions. The assigned designations are:

Note: Colors refer to Munsell Color Chart descriptions.

A. 10YR4/2 dark grayish brown fine sandy loam.

B. 10YR3/1 very dark gray sandy clay.

C. 10YR6/2 light brownish gray loamy clay.

The profile revealed in Test Unit 256-2 was

A, $15 \mathrm{~cm} . ; \mathrm{B}, 30 \mathrm{~cm}$; C, $5 \mathrm{~cm}$. No cultural evidence was encountered.

Unit 256-3.

This unit was placed $60 \mathrm{~m}$. north of highline pole structure no. 2 (fig. 6 ) and 15m. west of the extant ditch. This location is within the perimeter of surface evidence for the reported site. The unit profile (Fig. 8) revealed was A, $20 \mathrm{~cm}$.; B, $30 \mathrm{~cm}$; C, $5 \mathrm{~cm}$. Two burnt clay nodules (wt. 4 gr.) were recovered within the upper $10 \mathrm{~cm}$. No other cultural evidence was encountered. The test was $110 \mathrm{~cm}$. $x 35 \mathrm{~cm}$. in size and $55 \mathrm{~cm}$. deep.

Unit 256-4.

This unit was placed $45 \mathrm{~m}$. north of highline pole structure no. 2 (Fig. 6 ) and $16 \mathrm{~m}$. west of the extant ditch. The unit profile revealed was A, 20cm.; B, $55 \mathrm{~cm}$; C, $5 \mathrm{~cm}$. No cultural evidence was encountered. The test was $110 \mathrm{~cm}$. $x 40 \mathrm{~cm}$. in size and $80 \mathrm{~cm}$. deep.

Unit 256-5.

This unit was placed $30 \mathrm{~m}$. north of highline pole structure no. 2 (Fig. 6 ) and $17 \mathrm{~m}$. west of the extant ditch. The test was $1 \mathrm{~m}$. $x 35 \mathrm{~cm}$. in size and $55 \mathrm{~cm}$. deep. The profile (Fig. 9) revealed was A, $10 \mathrm{~cm}$; B, $40 \mathrm{~cm}$; C, $5 \mathrm{~cm}$. Five burnt clay nodules (wt. $7 \mathrm{gr}$. ) were recovered in the upper $10 \mathrm{~cm}$. No other cultural evidence was encountered. 
Unit $256-6$.

This unit was placed $15 \mathrm{~m}$. north of highline pole structure no. 2 (Fig. 6) and 14m. west of the extant ditch. The test was lm. $x 40 \mathrm{~cm}$. in size and $60 \mathrm{~cm}$. deep. The profile (Fig. 10). revealed was A, $10 \mathrm{~cm}$.; B, $45 \mathrm{~cm}$; C. $5 \mathrm{~cm}$. One clay nodule (wt.2gr.) was recovered in the upper $10 \mathrm{~cm}$. Three other nodules appeared in the profile in Level I I (10-20cm.). No other cultural evidence was encountered.

Unit $256-7$.

This unit was placed $15 \mathrm{~m}$. south of highline pole structure no. 2 (Fig.6) and 15m. west of the extant ditch. The test was $1 \mathrm{~m} . x 35 \mathrm{~cm}$. in size and $50 \mathrm{~cm}$. deep. The profile revealed was A, $15 \mathrm{~cm}$; B, $30 \mathrm{~cm}$; C, $5 \mathrm{~cm}$. No cultural evidence was encountered.

Unit $256-8$.

This unit was placed $10 \mathrm{~m}$. east of highline pole structure no. 2 in the edge of the west bank of the extant ditch. Purpose of the test was to locate the original profile of the ditch to see if it had impacted on any cultural resources during its original construction. The test was $180 \mathrm{~cm}$. $x 70 \mathrm{~cm}$. in size and $120 \mathrm{~cm}$. deep. The profile (Fig. 12) revealed that the ditch bank had been badly disturbed probably during repeated cleaning operations and episodes of spoil being spread on the slope during farming operations. For a complete description of the profile the reader is referred to Figure 12. Since no cultural evidence was encountered and because of the disturbed nature of the soil the test was terminated at $120 \mathrm{~cm}$. depth and $180 \mathrm{~cm}$. into the ditch bank.

Unit 256-9.

This unit was placed $12 \mathrm{~m}$. north of highline pole structure no. 2 (Fig. 6) and 8m. east of the eastern edge of the extant ditch. The test was $1 \mathrm{~m}$. $\mathrm{x} 40 \mathrm{~cm}$. in size and $70 \mathrm{~cm}$. deep. It was the only test east of the ditch because surface evi- 
dence was almost non-existent east of the ditch and no evidence was encountered beneath the surface.

The profile revealed (Fig. 11) was different from those west of the ditch, but the difference is attributed to modern farming practices and not Aboriginal utilization. The "A" horizon of the unit profile was identical with those previously described and $15 \mathrm{~cm}$. thick. However, at this point the soil encountered was a black (7.5YRN2/1) heavy clay which was hard to dig and impossible to screen. The test was abandoned at $70 \mathrm{~cm}$. without encountering the usual light colored subsoil as in the other tests.

In the upper $40 \mathrm{~cm}$. of the profile two vertical deposits of gray clayey silt (10YR5/1) were revealed which are thought to be chisel marks remaining from past episodes of chiselling or fertilizing operations. The light colored silt in these marks washes down from the surface during the first rain following the chiselling operation.

The field east of the extant ditch is operated by Texas A \& M University as an agricultural experiment station which utilizes a number of experimental tillage practices not used by the average area farmer. It is believed that the dark soil color in this test is caused by a high organic matter and fertilizer element content in the soil (due to experimental farming practices) or a change in soil type. The soil survey map (Franki et al 1965:sheet 27) of this area notes a delineation where Orelia fine sandy loam soils blend into Victoria clay in the immediate vicinity of Site 41NU256. Victoria clays are inherently darker and heavier clays than Orelia soils.

As noted above, no Aboriginal culural evidence was encountered in this test unit.

Unit 256-10.

This unit was placed $25 \mathrm{~m}$. north of highline pole structure no. 2 (Fig. 6) and 10m. west of the extant ditch. Purpose of this unit was to test an area within the site which appeared (from surface evidence and previous tests) to be likely to yield a good sample of artifacts and a profile of 
that portion of the site which was believed to be possibly intact beneath the spoil bank from ditch construction and cleaning episodes. The test was $120 \mathrm{~cm}$. $x \mathrm{~lm}$. in size and $90 \mathrm{~cm}$. deep. The profile (Fig. 13) revealed was A, $5 \mathrm{~cm}$; $B, 35 \mathrm{~cm}$; ; $C$, $50 \mathrm{~cm}$. In the lower $15 \mathrm{~cm}$. of the "B" horizon the profile revealed a scattering of finely fractured Rabdotus snail shells and two small burnt clay nodules. Also 3 clay nodules (wt. 4gr.) were collected in the upper $10 \mathrm{~cm}$. of the unit. No other cultural evidence was encountered.

Site 41NU257:

Surface Survey:

Since the site area west of the creek had been disked subsequent to the original survey this portion of the site was re-surveyed prior to testing. Numerous burnt clay nodules and scattered oyster shell fragments were observed on the surface. As in the original survey the surface evidence was heavier outside the drainage right-of-way west of highline pole structure no. 7. Collected during the survey were 4 Rangia shells, 1 chert hammer, 1 Catán dart point, 1 expended chert core, 3 percussion flakes ( 2 utilized), and 1 utilized chert chip (see artifact analysis below). A number of other chert fragments were collected and discarded in the laboratory as modern relics from concrete debris along the edge of the extant ditch.

\section{The Subsurface Tests:}

Unit 257-1.

This unit was placed $45 \mathrm{~m}$. north of highline pole structure no. 7 (Fig.7) and 12m. west of the extant ditch. The test was $1 \mathrm{~m}$. $x 35 \mathrm{~cm}$. in size and $50 \mathrm{~cm}$. deep. The profile revealed was similar to those in site $41 \mathrm{NU} 256$; $\mathrm{A}, 15 \mathrm{~cm}$; B, $25 \mathrm{~cm}$; C, $10 \mathrm{~cm}$.

No cultural evidence was encountered.

Unit 257-2.

This unit was placed $30 \mathrm{~m}$. north of highline pole structure no. 7 (Fig. 7) and $12 \mathrm{~m}$. west of the extant ditch. The 
test was $1 \mathrm{~m}$. $x 35 \mathrm{~cm}$. in size and $45 \mathrm{~cm}$. deep. The profile (Fig. 14) revealed was A, $10 \mathrm{~cm}$; B, $30 \mathrm{~cm}$; C, $5 \mathrm{~cm}$. Two clay nodules were collected in Level II $(10-20 \mathrm{~cm})$. and three others were observed in the profile in this same level as well as a few tiny charcoal flecks and Rabdotus shell fragments. No other cultural evidence was encountered.

Unit 257-3.

This unit was placed $15 \mathrm{~m}$. north of highline pole structure no. 7 (Fig. 7) and $10 \mathrm{~m}$. west of the extant ditch. The test was $110 \mathrm{~cm}$. $x 40 \mathrm{~cm}$. in size and $62 \mathrm{~cm}$. deep. The profile (Fig. 15) revealed was A, $2 \mathrm{~cm}$; B, $55 \mathrm{~cm}$; C, $5 \mathrm{~cm}$. The first 3 levels $(0-30 \mathrm{~cm})$ contained a great amount of tiny clay nodules, charcoal flecks and Rabdotus shell fragments. Level I I (10-20 cm.) had the heaviest accumulation and also yielded 2 Rangia shell fragments, and 3 Rabdotus snail shells as well as 7 clay nodules (wt. 36gr.). The other levels yielding artifacts were: Level I, 8 nodules (wt. 14gr.); Level IV, 1 nodule (wt. 15gr.). Level III yielded no nodules larger than $1 / 4$ inch. It seems most likely that the one clay nodule from level IV was translocated from a higher level possibly in a dry-weather crack which is common in heavy clay soils.

Unit 257-4.

This unit was placed $15 \mathrm{~m}$. south of highline pole structure no. 7 (Fig. 7) and 12m. west of the extant ditch. The test was $1 \mathrm{~m}$. $\times 35 \mathrm{~cm}$. in size and $50 \mathrm{~cm}$. deep. The profile revealed was $A, 3 \mathrm{~cm}$; $B, 42 \mathrm{~cm}$; C, $5 \mathrm{~cm}$. Levels I and I I $(0-20 \mathrm{~cm}$ ) yielded only 11 small clay nodules (wt. 21gr.). No cultural strata or other cultural evidence were observed.

Unit 257-5.

This unit was placed $30 \mathrm{~m}$. south of highline pole structure no. 7 (Fig. 7) and $14 \mathrm{~m}$. west of the extant ditch. The test was $1 \mathrm{~m}$. $x 30 \mathrm{~cm}$. in size and $80 \mathrm{~cm}$. deep. The profile revealed was $A, 5 \mathrm{~cm}$; $B, 40 \mathrm{~cm}$; $C, 35 \mathrm{~cm}$. This unit 
was excavated $35 \mathrm{~cm}$. into the light colored subsoil to assure that the profile below the plow zone (0 to 30 or $40 \mathrm{~cm}$.) was undisturbed and contained no cultural evidence. Level I yielded 3 clay nodules (wt. 8gr.), 1 Rabdotus shell, and 1 small fragment of unidentified bone. No cultural strata or other cultural evidence were observed.

Unit $257-6$

This unit was placed $5 \mathrm{~m}$. north of highline pole structure no. 7 (Fig.7) and 8m. west of the extant ditch. The test was $110 \mathrm{~cm}$. square and $80 \mathrm{~cm}$ deep. Purpose of this unit was to expose a larger surface area and deeper profile than the previous shovel tests. The profile (fig. 16) revealed was A, $10 \mathrm{~cm}$; B, $20 \mathrm{~cm}$; C, $50 \mathrm{~cm}$. The "B" horizon was darker black than the other tests, but similar in content to those near it (257-3, 257-4) revealing Levels I I and I I I containing a scattering of small fragments of Rabdotus shell and small clay nodules in the profile. A total of 45 clay nodules was collected (wt. 70gr.) from the two levels which were disturbed by farming operations. No Rabdotus shells were collected because they were highly fragmented and randomly distributed in the matrix.

The dark color of the "B" horizon (Fig. 16) is attributed to the presence of this test in Victoria Series soil as opposed to Orelia as in most of the other tests. Victoria soils are heavier clays and darker colored than Orelia (Franki, et a 1 1965:17). The soils map in Franki (1965) shows a division within the approximate limits of Site 41 NU257 between Victoria and Orelia Series soils.

No undisturbed cultural evidence was observed in this test unit.

Unit 257-7.

This unit was placed $15 \mathrm{~m}$. east of highline pole structure no. 7 in the brink of the eastern edge of the extant ditch (Fig. 7). The test was approximately $180 \mathrm{~cm} \times 50 \mathrm{~cm}$. in size and $180 \mathrm{~cm}$ deep (Fig. 17). Purpose of this unit was to 
attempt locating the original profile of the east bank of the ditch to determine if it had impacted upon any cultural resources during its construction.

One interesting natural feature encountered was a series of dry-weather cracks paralleling the ditch at the crest of the backslope (Fig. 17). This area is slightly mounded with spoil from ditch construction and maintenance so that it is artificially droughthy. Rainwater runs off very fast and no water stands on the crest. Also this particular portion of the field (and Site 41NU257) is adjacent to a grassed waterway on the Texas A \& M property and therefore is not cultivated. For these reasons the cracks form more readily, last longer, and are probably wider and deeper than those in more level areas which are cultivated periodically.

The two cracks encountered in this test were $5-10 \mathrm{~cm}$. wide and a $\mathrm{lm}$. rule did not reach the bottom of either. The phenomenon of dry-weather cracks has been discussed briefly above and is expanded upon below considering the impact upon archeological sites in heavy clay soils.

The profile revealed in this test (Fig. 17) was A, $20 \mathrm{~cm}$.; B, $80 \mathrm{~cm}$; C, $80 \mathrm{~cm}$. The undisturbed portion of the profile is covered with a stratum of spoil from the extant ditch.

No cultural evidence was observed in this unit.

Unit 257-8.

This unit was placed $45 \mathrm{~m}$. south of highline pole structure no. 7 (Fig. 7) and 15m. west of the extant ditch. The test was $1 \mathrm{~m}$. $x 35 \mathrm{~cm}$. in size and $55 \mathrm{~cm}$. deep. The profile revealed was A, $10 \mathrm{~cm}$; B, $40 \mathrm{~cm}$; C, $5 \mathrm{~cm}$.

No cultural evidence was observed.

Unit 257-9.

This unit was placed $60 \mathrm{~m}$. south of highline pole structure no. 7 (Fig. 7 ) and $15 \mathrm{~m}$. west of the extant ditch. The test was $1 \mathrm{~m}$. $x 35 \mathrm{~cm}$. in size and $65 \mathrm{~cm}$. deep. The profile revealed was $A, 15 \mathrm{~cm}$; B, $45 \mathrm{~cm}$; C, $5 \mathrm{~cm}$. No cultural evidence was observed. 
Assessment and Discussion

As a result of this series of subsurface tests it appears that sites 41 NU256 and 41 NU257 were situated either on the modern soil surface or within the upper $20-30 \mathrm{~cm}$. when the land.was cleared for cultivation. Subsequent farming operations have destroyed any intact cultural features and occupational surfaces which may have remained following initial clearing of the land within the 100ft. drainage rightof-way (R.O.W.).

Most of the surface evidence and all of the subsurface evidence of Aboriginal occupation is confined to the west side of the extant ditch. At site 41 NU256 the density of surface evidence is about equal within the R.O.W. and to the west adjacent to the R.O.W. indicating that the present tests were placed within the main body of the site. The paucity of subsurface remains at this site indicates a small, shortterm occupation. It is suggested that this site may have been a small satellite of Site 41NU257 which served some particular function (unknown) or may have been an area where the occupants of site 41 NU257 moved over and occupied a site further from Oso Creek for a brief period for whatever reason.

The density of surface evidence at site 41 NU257 is much heavier to the west of the ditch R.O.W. indicating that the present tests were near the eastern periphery of the site with the main occupation being west of the test units and outside the R.O.W. Subsurface evidence observed in the test profiles indicates greater density and depth of cultural debris near the center of the line of tests (257-3, 257-4, 257-6) which suggests that the main body of the site is situated west of the R.O.W. adjacent to these three test units. Density and depth of evidence and areal extent of surface artifacts suggest that Site 41 NU257 was a long-term (probably repeated temporary episodes) occupation site involved with marine (oyster, whelk), and brackish water (Ran- 
gia) shellfish utilization and possibly land snail (Rabdotus) processing as well as chert knapping activities. The effects of deep, dry-weather cracks in heavy clay soils such as those in the immediate area have been discussed above, but should be mentioned here as a reminder to investigators working in these types of soils. It is not uncommon for cracks to be $6-8 \mathrm{~cm}$. wide and $80 \mathrm{~cm}$. deep during dry periods. Any artifacts on the surface or in the profiles of these cracks are subject to downward translocation in the soil profile while the cracks are open. During the first few minutes of rain the upper edges of the cracks crumble and fall down the crack and light silty particles from the surface are also carried by runoff into the cracks. Usually in a good, moist, clean test profile previous evidence of cracks can be clearly observed as irregular, light colored (lighter than surrounding soil) scars extending vertically (sometimes horizontally) into the profile. Many times on high density sites artifacts may be found in these scars well below the level of occupation in a profile or within the occupation zone, but intrusive from above. Lenticular-shaped artifacts such as oyster and clam shells, chert tools and projectiles, or lengthy objects such as longbones are easily detected as being translocated in cracks since they tend to lie vertically in the confines of the crack. Also if there is a large number of pieces such as a shell midden involved the shells will many times be stacked one upon the other, but the individual specimens will be vertically oriented (standing-on-edge). The scars left from dry-weather cracks do not always leave a light-colored profile. Sometimes the soil which runs down into the open crack is similar to the adjacent profile. In this case the presence of an artifact vertically oriented may be the only easily visible indicator of translocation. If confirmation is desired a sample of the matrix immediately surrounding the specimen and another a few centimeters to either side 
may be analyzed. There should be a difference in soil texture and possibly other characteristics such as organic matter content, micro faunal presence, and other evidence of surface contamination between the two matrices.

Significance Determination

Since no intact evidence of previous occupation was located at either site 41 NU256 or 41 NU257 it is considered unnecessary to attempt a determination of significance for either site.

Temporal placement of Site 41 NU256 is not possible from the evidence gathered during the survey or testing phases of this project. It is estimated by the author to belong to the Late Archaic simply from the presence of shell, chert debitage, and burnt clay nodules, similar to other Late Archaic sites, its shallow profile near the surface and the absence of ceramics and/or arrowpoints.

Site 41 NU257 is tentatively assigned to the Late Archaic and possibly extending into the Late Prehistoric Period by the presence of one Catán dart point. Similar to 41 NU256 the absence of ceramics and arrowpoints leads the author to favor the Late Archaic Period even though catán points are found on Late Prehistoric sites (Ricklis, 1987; Turner and Hester 1985).

\section{Recommendations}

Since no significant cultural evidence and no sites listed or considered eligible for nomination to the National Register of Historic Place or State Archeological Landmarks have been identified within the project rightof-way it is recommended by the author that the project should proceed as planned by the sponsor.

Also recommended is the previously recommended and agreed-upon monitoring of that portion of the proposed ditch near Oso Creek (south of Site 41NU257) during earthmoving operations concerned with the construction phase of 
the project.

Since Oso Creek and its surroundings are archeologically sensitive areas, it is imperative that the project sponsor, its representatives, and contractors be alert to the possibility of encountering cultural evidence, including human remains, during the project. If such evidence is encountered all soil disturbing operations should be discontinued in the immediate area and the State Historic Preservation officer should be notified immediately in order that significance of the evidence might be determined by a competent archeologist prior to further disturbance. 
$\underline{\text { References Cited }}$

Basket, J. N.

1907-A Study of the Route of Cabeza de Vaca. South western Historical Quarterly Vol. 10, pp. 246-279.

Blair, W. R.

1950-The Biotic Provinces of Texas. Texas Journal of Science. Vol. 2, No. 1, pp. 93-117.

Bolton, H. E.

1970-Texas in the Middle Eighteenth Century. University of Texas Press, Austin, Texas.

Carlson,D.L.; D.G.Steele and H.L. Bruno.

1982-Archeological Investigations at the Allison Site (41NU185), Nueces County, Texas. Texas A \& M University, College Station, Texas.

Deviney, M. L.

1933- The History of Nueces County to 1850. M.A. Thesis. The University of Texas. Austin, Texas.

Franki, G. E., R.N. Garcia, B. F. Hajek, D. Arriago and J. C. Roberts.

1965- Soil Survey of Nueces County, Texas. U.S.D. A. Soil Conservation Service and Texas Agricultural Experiment Station.

Gould, F. พ.

1962-Texas Plants-A Checklist and Ecological Summary. Texas A \& M College and Texas Agricultural Experiment Station. college Station, Texas.

Kier, R. S., L. E. Garner and L. F. Brown, Jr.

1977-Land Resources of Texas. Bureau of Economic Geology. The University of Texas, Austin, Texas.

Patterson, P. E. and M. M. Ford

1974- Oso Creek Flood Control Project Area, Nueces County, Texas. A Report on The Archeological and Historical Resources. Texas Archeological Survey Report No. 35, The University of Texas, Austin, Texas.

Ricklis, R.A.

1988- Archeological Investigations at the McKenzie Site (41NU221), Nueces County, Texas: Description and Contextual Interpretations. in Bulletin of the Texas Archeological Society, No.58,1987.

Riley, M. C.

1951- The History of The Development of The Port of Corpus Christi. M. A. Thesis. The University of Texas, Austin, Texas. 
Smith, H. A. and J. E. Deisler, K. Cox, J. Warren, J. Bauman . 1985- The Tucker Site, 41NU46, An Archaic settlement on The Lower Texas Coast. C. C. Museum, Corpus Christi, Texas.

1988- Personal Communication during survey.

Turner,E.S. and T.R. Hester.

1985- A Field Guide to Stone Artifacts of Texas Indians. Texas Monthly Press, Austin, Texas.

Warren, J.E.

1984- A Cultural Resources Survey of the King's Crossing Development, Lower Oso Creek Area, Nueces County, Texas. C.C. Land Venture, Inc., Corpus Christi, Texas.

1988- A Cultural Resources Survey of the De Dietrich (USA), Inc. Project Site, Nueces County, Texas. City of Corpus Christi, Texas.

Webb, W. P. (Editor-in-Chief)

1952- The Handbook of Texas, Vols. I and II. The Texas State Historical Association, Austin, Texas. 